Journal of

Dentistry and Oral Health

\title{
Comparison of the XP-Endo Finisher File System and Passive Ultrasonic Irrigation (PUI) on Smear Layer Removal after Root Canal Instrumentation Effectiveness of Two Irrigation Methods on Smear Layer Removal
}

\author{
Daniel Sanabria-Liviac ${ }^{1}$, Bertram Ivan Moldauer ${ }^{2,}$, Franklin Garcia-Godoy ${ }^{3}$, Abel Antonio-Campos ${ }^{4}$, \\ Mario Casaretto ${ }^{5}$, John Torres-Navarro ${ }^{6}$, Jon-Michael Scalercio ${ }^{7}$ \\ ${ }^{1}$ Postgraduate Endodontic Resident, Garcilaso de la Vega University, Lima Peru \\ ${ }^{2}$ Adjunct Assistant Professor in Endodontics, Nova Southeastern University, Ft. Lauderdale, Fl \\ ${ }^{3}$ Senior Executive Associate Dean for Research, University of Tennessee, College of Dentistry \\ ${ }^{4}$ Postgraduate Endodontic Resident, Garcilaso de la Vega University, Lima Peru \\ ${ }^{5}$ Associate Professor, Chairman of Endodontics and Director of Advanced Education Programs, Garcilaso de la \\ Vega University, Lima Peru \\ ${ }^{6}$ Associate Professor, Director of Postgraduate Endodontics, Garcilaso de la Vega University, Lima Peru \\ ${ }^{7}$ Dental student, Nova Southeastern University, Ft. Lauderdale, Fl
}

${ }^{\star}$ Corresponding author: Bertram Ivan Moldauer, Adjunct Assistant Professor, Department of Endodontics, College of Dental Medicine, Nova Southeastern University, 3200 S. University Dr. Fort Lauderdale, FL 33328-2018, USA, Tel: (954) 262 1753, Fax: (954) 262 1782; E-mail: bmolda@nova.edu

Received Date: December 30 2016; Accepted Date: January 10 2017; Published Date: January 122017

Citation: Daniel Sanabria-Liviac, et al. (2017) Comparison of the XP-Endo Finisher File System and Passive Ultrasonic Irrigation (PUI) on Smear Layer Removal after Root Canal Instrumentation. J Dent Oral Health 4: 1-7

\begin{abstract}
Objectives: The purpose of this study was to evaluate the effectiveness of two different final irrigant activation methods in removing the smear layer at 3 and $7 \mathrm{~mm}$ from the apex.

Methods: Thirty-six extracted single-rooted human mandibular premolars were instrumented by a reciprocating Wave-One 40.08 (Dentsply Maillefer, Switzerland) and irrigated with $2.5 \mathrm{ml} .2 .5 \% \mathrm{NaOCl}$ at $37 \mathrm{C}^{\circ}$. Teeth were divided into four groups according to the final irrigant activation technique (Group 1: XP-Endo Finisher File NaOCl 2.5\% /EDTA 17\%; Group 2: XP-Endo Finisher File NaOCl 2.5\%; Group 3: passive ultrasonic irrigation [PUI] NaOCl 2.5\% /EDTA 17\% and Group 4: PUI-NaOCl 2.5\%). Root canals were then split longitudinally and observed by field emission scanning electron microscopy. The percentage of area of open dentinal tubules was evaluated. Data were analyzed using the Kolmogorov-Smirnov and two factor ANOVA.

Results: In all groups, the middle third of the roots demonstrated a significant higher percentage of dentinal tubules free of smear layer compared to the apical third $(\mathrm{p}<0.05)$. The XP Endo-finisher $\mathrm{NaOCl} / \mathrm{EDTA}$ group showed a higher percentage of open dentinal tubules for the middle and apical thirds $(\mathrm{P}<0.001)$. Group 3 (PUI NaOCl/EDTA) removed more smear layer at both root thirds than groups 2 (XP Endo-finisher $\mathrm{NaOCl}$ ) and 4 (PUI NaOCl) respectively $(\mathrm{p}<0.001)$.

Conclusions: None of the systems eliminated the smear layer; nevertheless, the XP-Endo-finisher NaOCl/EDTA group was more effective than PUI with and without EDTA for smear layer removal at both middle and apical canal thirds.

Clinical significance: The use of the XP-Endo-finisher file system is an effective method for smear layer removal after root canal instrumentation.
\end{abstract}

Keywords: XP-Endo Finisher File; Irrigant activation; Passive ultrasonic activation; Root canal irrigation; Smear layer

(C)2017 The Authors. Published by the JScholar under the terms of the Creative Commons Attribution License http://creativecommons.org/licenses/ by/3.0/, which permits unrestricted use, provided the original author and source are credited. 


\section{Introduction}

Chemo-mechanical instrumentation is of vital importance for the successful treatment outcome in non-surgical endodontic therapy [1]. During the cleaning and shaping process, organic pulpal remnants and inorganic dentinal debris accumulate and adhere onto the radicular canal wall producing an amorphous irregular smear layer [2]. The use of both hand and rotary instruments create smear layer of different thickness on the canal walls as a consequence of the denting cutting action [3]. The organic component of the smear layer might constitute a proper substrate for bacterial growth; in addition it might interfere with sealer adhesion onto the canal wall and allow leakage to take place [4]. Some studies [5], have suggested that viable microorganisms in the dentinal tubules may use the smear layer as a reservoir for sustained growth and replication. If the smear layer is left intact, it may slowly dissolve with leaking obturation materials, or it may be removed by acids and enzymes that are produced by viable microorganisms left in the tubules or by bacteria that gain entrance via coronal leakage [6].

According to Orstavik et al. [7], the presence of a smear layer may also inhibit the action and effectiveness of root canal irrigants and inter-appointment medicaments. Oksan and coworkers [8], have concluded that removing the smear layer will allow better adaptation of obturation materials to the canal wall; this has also been demonstrated by Wennberg et al. [9], and by Leonard et al. [10], who demonstrated better adhesion and tubular penetration of sealers into dentin once the smear layer had been removed. Sodium hypochlorite $(\mathrm{NaOCl})$, a deproteinizing agent has become the most popular irrigating solution in endodontics [11], and its alternate use with EDTA, a calcium-chelating agent, has been recommended for the efficient removal of the smear layer $[12,13]$. To improve cleanliness, irrigants should be in contact with root canals [14]. The traditional needle irrigation technique delivers solutions no more than $0-1.1 \mathrm{~mm}$ beyond the needle tip [15]. This is insufficient for complete cleaning of the complex anatomy of the root canal system (lateral canals, isthmus, fins, and accessory canals [16].

Different devices for irrigation delivery have been proposed to increase the flow and distribution of irrigating solutions within the root canal system [17]. Recently the XP- Endo Finisher ${ }^{\text {Tx }}$ file (Brasseler USA ${ }^{\oplus}$, Savannah, Georgia) has been introduced to the market. According to the manufacturer the file has a semi-circular shape with a $3 \mathrm{~mm}$ diameter that enables it to transform into any canal shape and reach irregularities, fins and resorptive areas. It is designed to be used with irrigants after initial root canal instrumentation with the aim of removing vital and/or necrotic tissues, and dentinal debris accumulated during instrumentation and smear layer [18]. A study by Elnaghy et al. [19], found that the utilizing the XP-endo Finisher file and the EndoActivator system resulted in less debris and lower smear layer scores than file agitation and the standard needle irrigation technique at the coronal, middle, and apical regions in curved canals.
Passive ultrasonic irrigation (PUI), first described by Weller et al. [20], uses a stainless steel file to activate the irrigant in the canal [21]. PUI is able to alter and eventually disrupt the endodontic biofilm, facilitating better penetration of irrigants throughout the endodontic dentinal walls [22]. Various studies have shown that ultrasonic activation of irrigating solutions as PUI promotes better removal of the smear layer in the apical and isthmus regions [23-25].

Currently, there are no studies between the XP-Endo Finisher File System and PUI for the evaluation of smear layer removal utilizing similar experimental protocols. A recent research study by Leoni et al. [26] found that the PUI technique and XPendo Finisher instrument were associated with significantly lower levels of accumulated hard tissue debris compared with conventional irrigation and the modified SAF system protocol in mesial root canals of mandibular molars.

Therefore, the aim of this study was to compare the efficacy of both systems regarding smear layer removal after root canal instrumentation

\section{Materials and Methods}

\section{Selection, Preparation and Classification of the Specimens}

Thirty-six human single-rooted non-carious mandibular premolars extracted for orthodontic purposes were randomly selected from the same age group (14- to 22-year-old patients) with the approval of the Ethics Committee for Scientific Research of the University Inca Garcilaso de la Vega, Lima, Peru. Teeth selected had no cracks, endodontic treatments, and restorations. Only teeth with intact and mature root apices and roots longer than $14 \mathrm{~mm}$ were selected. Teeth were then $\mathrm{x}$-rayed buccolingually and mesiodistally to confirm straight single canals and the canal space size. Teeth with root canal curvatures greater than $20^{\circ}$ or calcified root canals were excluded. After extraction, teeth were stored in $2 \%$ thymol solution at room temperature and used within 1 week. Inclusion and exclusion criteria were verified under a $20 \mathrm{X}$ magnification laboratory microscope (AmScope SE308-P Binocular Stereo Microscope, Irvine, California USA). After the access cavity was created, a \#10 K-file (Dentsply Maillefer, Ballaigues, Switzerland) was inserted into the canal until the instrument tip was barely visible at the apical foramen. The root lengths were standardized to $16 \mathrm{~mm}$ by decoronation of the tooth perpendicular to the long axis by means of a high-speed, water-cooled diamond disc. To simulate clinical conditions, apices were sealed with hot glue, and to prevent the glue from entering the canal, a \#10 K-file was inserted before the apex was sealed. Root canal preparations were performed by the same operator using the Pro-Train endodontic training system for tooth preparation standardization (Simit Dental, Mantova, Italy). The specimens were shaped by means of the Wave One 40.08 nickel-titanium single file reciprocating system (Dentsply Maillefer, Ballaigues, Switzerland) according to the manufacturer's instructions until the file reached the working length (WL). Each instrument was used to shape only 4 specimens. After each instrumentation and before the next, canals were rinsed with $2.5 \mathrm{~mL} 2.5 \%$ $\mathrm{NaOCl}$ at $37 \mathrm{C}^{\circ}$ (Chematek SpA, Rome, Italy). 
The apical patency was checked after each instrument with a \#10 K-file. Irrigating solutions were delivered by means of a 30-G syringe needle (NaviTip; Ultradent, South Jordan, UT) inserted deeply at $1 \mathrm{~mm}$ from the working length.

All specimens were then irrigated with $2.5 \mathrm{ml}$ distilled water. The specimens were then dried with sterile paper points and assigned randomly to each of four groups for final activation (Table 1). All specimens were then irrigated with $2.0 \mathrm{ml}$ distilled water and dried with sterile paper points.
Using that magnification 3 areas were selected randomly at the same positions ( 3 and $7 \mathrm{~mm}$ from the apex) and evaluated at X5000 magnification (Figure. 1).

Two observers performed blind evaluations independently after examining 12 specimens for calibration purposes.

\begin{tabular}{|l|l|l|l|l|}
\hline Group Name & $\mathrm{n}$ & Shaping & Activation & Protocols \\
\hline $\begin{array}{l}\text { XP-Endo Finisher } \\
\text { NaOCl-EDTA }\end{array}$ & 9 & Yes & Yes & $\begin{array}{l}\text { Final rinse with 2ml 2.5\% NaOCl activated for 1 minute to working } \\
\text { length, followed by 2ml distilled water, and finally 2ml 17\% EDTA ac- } \\
\text { tivated for 1 minute to working length, followed by 2ml distilled water } \\
\text { rinse, then 2ml 2.5\% NaOCl activated for 1 minute to working length. }\end{array}$ \\
\hline $\begin{array}{l}\text { XP-Endo Finisher } \\
\text { NaOCl }\end{array}$ & 9 & Yes & Yes & $\begin{array}{l}\text { Final rinse with 2ml 2.5\% NaOCl activated for 1 minute to working } \\
\text { length. }\end{array}$ \\
\hline $\begin{array}{l}\text { PUI NSK Varios 350 } \\
\text { NaOCl-EDTA }\end{array}$ & 9 & Yes & Yes & $\begin{array}{l}\text { Final rinse with 2ml 2.5\% NaOCl activated for 1 minute with PUI } \\
\text { with Irrisonic using NSK Varios 350 at working length, followed by } \\
\text { 2ml distilled water rinse, then 2ml 17\% EDTA activated for 1 minute } \\
\text { to working length, followed by 2ml distilled water rinse, then 2ml } \\
\text { 2.5\% NaOCl activated for 1 minute to working length. }\end{array}$ \\
\hline $\begin{array}{l}\text { PUI NSK Varios 350 } \\
\text { NaOCl }\end{array}$ & Yes & Yes & $\begin{array}{l}\text { Final rinse with 2 ml 2.5\% NaOCl activated for 1 minute with PUI with } \\
\text { Irrisonic using NSK Varios 350 to working length. }\end{array}$ \\
\hline
\end{tabular}

Table 1. Experimental Groups and Protocols

\section{Specimen Preparation}

Field emission scanning electron microscopy was used to evaluate endodontic smear layer removal from the instrumented root canals. To facilitate fracture into halves, all roots were grooved longitudinally on the external surface with a diamond disc without penetration into the root canals. The roots were then split into halves with a chisel with a Wave-One large gutta-percha cone in the root canal to limit tooth fragments covering endodontic canal walls. For each root, the half containing the most visible part of the endodontic wall was conserved and coded. The coded specimens were secured on metal stubs, desiccated, and viewed with field emission scanning electron microscopy (FEI COMPANY; Inspect S50, Hillsboro, OR, USA). The main operating parameters of the instrument were $5 \mathrm{KeV}$ as gun voltage and a working distance of about $11 \mu \mathrm{m}$; both parameters were chosen to avoid an excessive charging of the specimens. Smear layer removal was evaluated by microphotographs taken at 3 and $7 \mathrm{~mm}$ from the apex at an initial magnification of X1500.

\section{Statistical Analysis}

Intra- and inter-examiner reliability for field emission scanning electron microscopic assessment was verified by the kappa test. The images taken at X 5000 were evaluated by using Image J version $1.50 \mathrm{e}$ to enable identification and expression of the percentage of area of open dentinal tubules in relation to the total area of the analyzed image. Data were analyzed using the Kolmogorov-Smirnov test to analyze the normality of the continuous variables. The combination of variables: "groups" and "canal thirds" demonstrated a normal distribution. The significant differences in the amount of smear layer removal by the final irrigation protocol were analyzed by using two factor analysis of variance (ANOVA). The analysis of variance was then used for multiple comparisons, with Bonferroni correction, to isolate the differences, which reduced the $\mathrm{P}$ value to 0.001 in all groups, with the exception of groups 2 and 4 for both canal thirds ( apical and middle) ( $\mathrm{p}>0.05)$. 

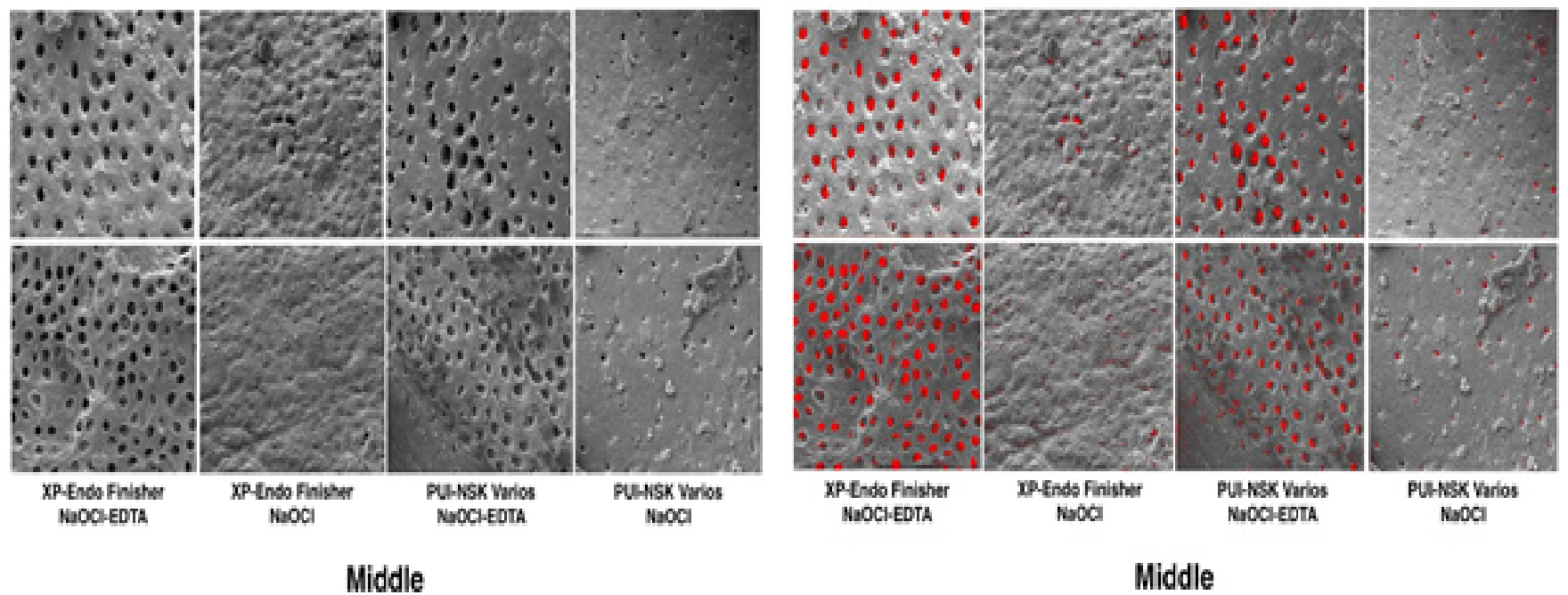

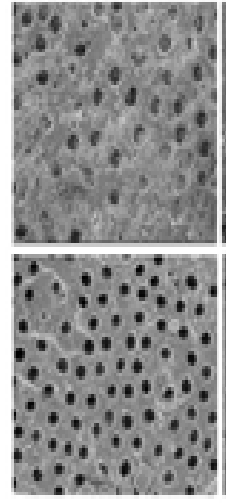

XP-Ende Fivighe NaCOEDTA

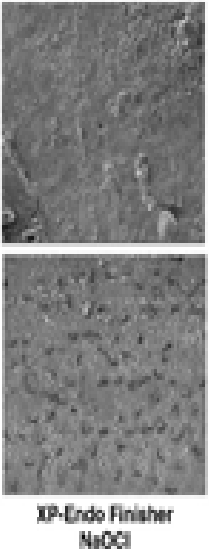

Apical

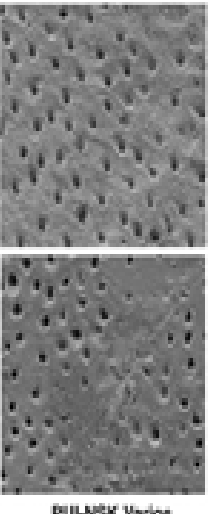

PUHESK Varios NaOSIEDTA

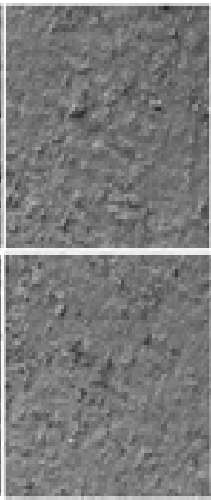

PUHNŚX Varios NoOC
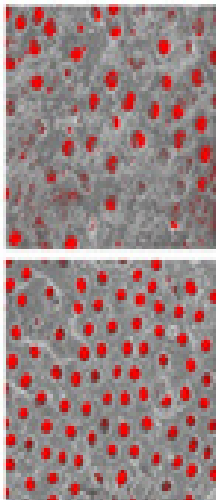

XP.Eade Fivisher NaOc-edta
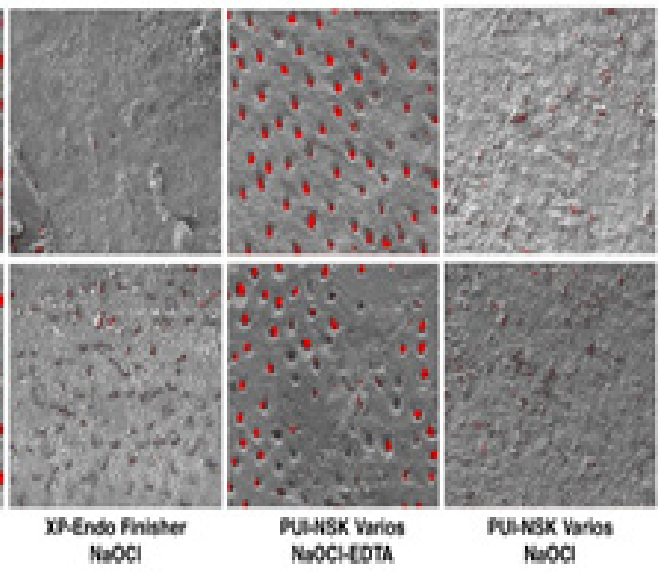

Apical

Figure 1. Representative SEM micrographs at 5000X showing selected samples from the middle and apical thirds representing the different final irrigation activation techniques and corresponding analysis using image J version $1.50 \mathrm{e}$ (right). The XP-Endo Finisher NaOCl-EDTA group showing a highly clean canal surface with patent dentinal tubules in the middle and apical thirds, with little debris and some smear plugs in the apical third. The XP-Endo Finisher NaOCl group showing a thick smear layer with no patent dentinal tubules, some debris in the middle third and similar findings in the apical third. The PUI- NSK Varios NaOClEDTA group showing a partial clean wall with smear plugs in the middle third, less patent tubules with more smear plugs in the apical third and a thick smear layer with few patent tubules in the apical third. The PUI-NSK Varios $\mathrm{NaOCl}$ group showing a thick smear layer with few patent dentinal tubules and debris in the middle thirds, the apical third exhibits a thick smear layer with no patent dentinal tubules.

\section{Results}

The results of smear layer removal amount in each of the experimental groups appear in Table 2 in the form of percentage distribution. Figure. 1 shows examples of smear layer removal in the middle, and apical thirds.

In all groups, the middle third demonstrated a significant higher percentage of dentinal tubules free of smear layer compared to the apical third $(\mathrm{p}<0.05)$. When comparing the amount of smear layer removal by all 4 groups for each root third, group 1(XP Endo-finisher NaOCl/EDTA) showed a higher statistically significant difference in the results of the middle third $(\mathrm{P}<0.001)$, and apical third $(\mathrm{P}<0.001)$.
There was also no significant difference between groups 2 (XP Endo finisher $\mathrm{NaOCl}$ ) and 4 (PUI NSK Varios $350 \mathrm{NaOCl}$ ) for both root thirds in terms of smear layer removal $(\mathrm{p}>0.05)$. The results also demonstrate that group 3 (PUI NSK Varios 350 $\mathrm{NaOCl} / \mathrm{EDTA}$ ) had a significant higher percentage of cleaner dentinal tubules at both root thirds than groups 2 (XP Endofinisher $\mathrm{NaOCl}$ ) and 4 (PUI NSK Varios $350 \mathrm{NaOCl}$ ) respectively $(\mathrm{p}<0.001)$. 


\begin{tabular}{|c|c|c|c|c|c|c|c|c|c|c|}
\hline GROUP & & dle Thir & & & & & Third & & & \\
\hline & $\mathrm{N}$ & Mean & 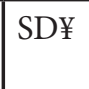 & $\begin{array}{l}\text { Differ- } \\
\text { ence } \dagger\end{array}$ & $\begin{array}{l}P-V \text { a } 1- \\
\text { uet† }\end{array}$ & $\mathrm{N}$ & Mean & SD¥ & $\begin{array}{l}\text { D if f e r - } \\
\text { encet }\end{array}$ & P-Value $\dagger \dagger$ \\
\hline XP-Endo Finisher/NaOCl-EDTA & 9 & 55.8 & 6.5 & & & 9 & 44.6 & 4.5 & & \\
\hline XP-Endo Finisher $/ \mathrm{NaOCl}$ & & & & 54.2 & $<0.001^{\star}$ & & & & 43.7 & $<0.001^{*}$ \\
\hline $\begin{array}{l}\text { PUI-NSK Varios/NaOCl- } \\
\text { EDTA }\end{array}$ & & & & 15.2 & $<0.001^{*}$ & & & & 19.8 & $<0.001^{*}$ \\
\hline PUI-NSK Varios/NaOCl & & & & 50.3 & $<0.001^{*}$ & & & & 42.5 & $<0.001^{*}$ \\
\hline XP-Endo Finisher/NaOCl & 9 & 1.6 & 0.2 & & & 9 & 1 & 0.2 & & \\
\hline $\begin{array}{l}\text { XP-Endo Finisher/NaOCl- } \\
\text { EDTA }\end{array}$ & & & & -54.2 & $<0.001^{\star}$ & & & & -43.7 & $<0.001^{\star}$ \\
\hline $\begin{array}{l}\text { PUI-NSK Varios/NaOCl- } \\
\text { EDTA }\end{array}$ & & & & -39 & $<0.001^{*}$ & & & & -23.8 & $<0.001^{*}$ \\
\hline PUI-NSK Varios/NaOCl & & & & -4 & $0.077^{\star \star}$ & & & & -1.2 & $1.000^{\star \star}$ \\
\hline PUI-NSK Varios/NaOCl-EDTA & 9 & 40.6 & 2.9 & & & 9 & 24.8 & 4 & & \\
\hline $\begin{array}{l}\text { XP-Endo Finisher/NaOCl- } \\
\text { EDTA }\end{array}$ & & & & -15.2 & $<0.001^{\star}$ & & & & -19.8 & $<0.001^{\star}$ \\
\hline XP-Endo Finisher/NaOCl & & & & 39 & $<0.001^{\star}$ & & & & 23.8 & $<0.001^{\star}$ \\
\hline PUI-NSK Varios/NaOCl & & & & 35 & $<0.001^{*}$ & & & & 22.6 & $<0.001^{*}$ \\
\hline PUI-NSK Varios/NaOCl & 9 & 5.6 & 0.6 & & & 9 & 2.2 & 0.3 & & \\
\hline $\begin{array}{l}\text { XP-Endo Finisher/NaOCl- } \\
\text { EDTA }\end{array}$ & & & & -50.3 & $<0.001^{\star}$ & & & & -42.5 & $<0.001^{\star}$ \\
\hline XP-Endo Finisher/NaOCl & & & & 4 & $0.077^{\star \star}$ & & & & 1.2 & $1.000^{\star \star}$ \\
\hline $\begin{array}{l}\text { PUI-NSK Varios/NaOCl-ED- } \\
\text { TA }\end{array}$ & & & & -35 & $<0.001^{*}$ & & & & -22.6 & $<0.001^{*}$ \\
\hline
\end{tabular}

$¥$ Standard Deviation

$\dagger$ Difference of marginal means between groups in relation to canal area

$\dagger \dagger$ Post-Hoc Bonferroni analytical comparison between marginal means

${ }^{\star}$ Statistical significant difference with a confidence interval of $99.9 \%(\mathrm{P}<0.001)$

${ }^{*}$ No statistical significant difference with a confidence interval of $95 \%(P>0.05)$

Table 2: Comparative analysis of final irrigation activation protocols in relation to percentage of smear layer removal at apical and middle canal thirds.

\section{Discussion}

Currently, several techniques and systems are available and reported to improve final irrigation before obturation [27]. The recommended combination is a final rinse of $15 \%$ or $17 \%$ EDTA solution followed by $1 \%-6 \%$ of $\mathrm{NaOCl}[12,28]$. However, there is no consensus on volume [28,29], time of application [30], or activation method [31,32] of irrigating solutions. The aim of this study was to compare the effectiveness of a new instrument the XP-Endo finisher file (Brasseler USA ${ }^{\circledR}$, Savannah, Georgia) with that of passive ultrasonic irrigation (PUI) in terms of smear layer removal. These activation techniques are different in their theory and mode of application.
Results of this study showed that as regards of percentage of open dentinal tubules scores for all canal thirds, the XP-Endo Finisher/NaOCl-EDTA group had the highest scores, with significant difference when compared to the other groups. This was followed by the PUI-NSK Varios/NaOCl-EDTA group and finally by the PUI-NSK Varios/NaOCl and XP-Endo Finisher/ $\mathrm{NaOCl}$ groups, which demonstrated the statistically lowest mean scores of open dentinal tubules. The efficiency of the XP-Endo finisher file might be attributed to several reasons. The first is its expansion capacity given its small core size- ISO 25 in diameter and its zero taper, the file exhibits good flexibility and ability to contact several areas of the canal walls. According to the manufacturer [18], the file can expand its reach $6 \mathrm{~mm}$ in diameter or 100 -fold of an equivalent sized file. The second is its shape-memory effect. 
The file is straight in its M-phase, which is achieved when it is cooled. When the file is exposed to the body temperature (inside the canal) it will change its shape due to its molecular memory to the A-phase. The A-phase shape in the rotation mode allows the file to access and clean areas that are otherwise impossible to reach with standard instruments.

The relatively lower smear removal scores achieved with PUI/ $\mathrm{NaOCl}-\mathrm{EDTA}$ in comparison to the XP-Endo finisher/NaOCl-EDTA group might be due to the size of the ultrasonic tip used (20/01), which might be very small for these larger canals (40/08). Also, the power setting used (power setting of 4- approx. 28khz) might be weak to allow a proper acoustic streaming with this small tip. This is in agreement with Jiang et al. [33], who found that a higher ultrasonic intensity results in higher amplitude of oscillation and, consequently, enhances the cleaning efficacy of PUI.

Another factor that could have influenced the results of the PUI/NaOCl-EDTA group in the present study could have been the time of application, concentration and volume of the irrigants used. Some authors have shown that the use of PUI for 3-5 minutes with $\mathrm{NaOCl}$ concentrations of $3 \%$ or $5 \%[34,35]$ is sufficient for the complete removal of the smear layer in instrumented root canals. In contrast, a time of application less than 1 minute did not allow for complete removal of the smear layer with $1 \% \mathrm{NaOCl}[36]$.

In this study, sodium hypochlorite without the activation of EDTA for both the PUI and the XP-Endo Finisher file groups did not remove smear layer, proving that irrigation with $\mathrm{NaO}-$ $\mathrm{Cl}$ alone is not effective. Baumgartner \& Cuenin [37] also observed that ultrasonically energized $\mathrm{NaOCl}$, even in higher concentrations such as $5.25 \%$, did not remove smear layer from the root canal walls.

Although the ability of PUI to remove the smear layer has been reported previously [38,25], our results showed that PUI was not superior to the XP-Endo finisher file under similar experimental conditions. This is in agreement with other studies $[39,40]$, which have demonstrated that PUI did not completely remove smear layers from the apical third of canal walls.

The results of this study are in accordance with previous studies [41-44], which have demonstrated that the most effective protocol for smear layer elimination might be related to the use of a final flush with $17 \%$ EDTA solution. Without a final activation with $17 \%$ EDTA solution, the smear layer was seen to cover the root canal surface in the middle and apical thirds, regardless of whether the XP-Endo finisher file or PUI was used.

\section{Conclusions}

Within the limitations of this study, the XP-Endo Finisher file in combination with $2.5 \% \mathrm{NaOCl}$ and EDTA $17 \%$ did enhance the removal of smear layer as compared with PUI activation with $2.5 \% \mathrm{NaOCl}$ and EDTA $17 \%$. The removal of smear layer was more complete in the middle third than in the apical third for all groups. Further research entailing different solutions, volumes, and activation times of the irrigants would be necessary to fully evaluate the effectiveness of the XP-Endo Finisher file system for smear layer removal after root canal instrumentation.

\section{References}

1) Sabeti MA, Nekofar M, Motahhary P, Ghandi M, Simon JH (2006) Healing of apical periodontitis after endodontic treatment with and without obturation in dogs. J Endod 32: 628-633.

2) Torabinejad M, Handysides R, Khademi AA, Bakland LK (2002) Clinical implications of the smear layer in endodontics: a review. Oral Surg Oral Med Oral Pathol Oral Radiol Endod 94: 658-666.

3) Violich DR, Chandler NP (2010) The smear layer in endodontics-a review. Int Endod J 43: 2-15.

4) Sen BH, Wesselink PR, Turkun M (1995) The smear layer-a phenomenon in root canal therapy. Int Endod J 28: 141-148.

5) Clark-Holke D, Drake D, Walton R, Rivera E, Guthmiller JM (2003) Bacterial penetration through canals of endodontically treated teeth in the presence or absence of the smear layer. J Dent 31:275-281.

6) Delivanis PD, Mattison GD, Mendel RW (1983) The survivability of F43 strain of Streptococcus sanguis in root canals filled with guttapercha and Procosol cement. J Endod 9: 407-410.

7) Orstavik D, Haapasalo M (1990) Disinfection by endodontic irrigants and dressings of experimentally infected dentinal tubules. Endod Dent Traumatol 6:142-149.

8) Oksan T, Aktener BO, Sen BH, Tezel H (1993) The penetration of root canal sealers into dentinal tubules. A scanning electron microscopic study. Int Endod J 26: 301-305.

9) Wennberg A, Orstavik D (1990) Adhesion of root canal sealers to bovine dentine and gutta-percha. Int Endodontic J 23: 13-19.

10) Leonard JE, Gutmann JL, Guo IY (1996) Apical and coronal seal of roots obturated with a dentine bonding agent and resin. Int. Endodontic J 29: 76-83.

11) Carson KR, Goodell GG, McClanahan SB (2005) Comparison of the antimicrobial activity of six irrigants on primary endodontic pathogens. J Endod31: 471-473.

12) Peters CA, Barbakow F (2000) Effect of irrigation on debris and smear layer on canal walls prepared by two rotary techniques: a scanning electron microscopic study. J Endod 25: 6-10.

13) Ciucchi B, Khettabi M, Holz J (1989) The effectiveness of different endodontic irrigation procedures on the removal of the smear layer: a scanning electron microscopic study. Int Endodontic J 22: 21-28.

14) Zehnder M (2006) Root canal irrigants. J Endod 32: 389-398.

15) Munoz HR, Camacho-Cuandra K (2012) In vivo efficacy of three different endodontic irrigation systems for irrigant delivery to working length of mesial canals of mandibular molars. J Endodontics 38: $445-448$.

16) Villas-Boas $\mathrm{MH}$, Bernardineli N, Cavalini Cavenago B, et al. (2011) Micro-computed tomography study of the internal anatomy of mesial root canals of mandibular molars. J Endodontics 37: 16821686. 
17) Gu LS, Kim JR, Ling J, Choi KK, Pashley DH, et al. (2009) Review of contemporary irrigant agitation techniques and devices. J Endod35: 791-804.

18) FKG Dentaire SA. XP-Endo Finisher.

19) Elnaghy AM, Mandorah, A, Elsaka, SE (2016) Effectiveness of XP-endo Finisher, EndoActivator, and File agitation on debris and smear layer removal in curved root canals: a comparative study. Odontology.

20) Weller RN, Brady JM, Bernier WE (1980) Efficacy of ultrasonic cleaning. J Endodontics 6: 740-743.

21) Ahmad M, Pitt Ford TJ, Crum LA (1987) Ultrasonic debridement of root canals: acoustic streaming and its possible role. J Endod13: 490-499.

22) Gu LS, Kim JR, Ling J, Choi KK, Pashley DH, et al. (2009) Review of contemporary irrigant agitation techniques and devices. J Endod 35: 791-804.

23) Kuah HG, Lui JN, Tseng PS, Chen NN (2009) The effect of EDTA with and without ultrasonics on removal of the smear layer. J Endod35: 393-396.

24) Jiang LM, Lak B, Eijsvogels LM, Wesselink P, van der Sluis LW (2012) Comparison of the cleaning efficacy of different final irrigation techniques. J Endod 38: 838-841.

25) Van der Sluis LW, Versluis M, Wu MK, Wesselink PR (2007) Passive ultrasonic irrigation of the root canal: a review of the literature. Int Endodontic J 40: 415-426.

26) Leoni GB, Versiani MA, Silva-Sousa YT, Bruniera JFB, Pecora JD, et al. (2016) Sousa-Neto MD. Ex vivo evaluation of four final irrigation protocols on the removal of hard-tissue debris from mesial root canal system of mandibular first molars. Int Endodontic J.

27) Boutsioukis C, Lambrianidis T, Kastrinakis E (2009) Irrigant flow within a prepared root canal using various flow rates: a computational fluid dynamics study. Int Endodontic J 42: 144-155.

28) Ciucchi B, Khettabi M, Holz J (1989) The effectiveness of different endodontic irrigation procedures on the removal of the smear layer: a scanning electron microscopic study. Int Endodontic J 22: 21-28.

29) Crumpton BJ, Goodell GG, McClanahan SB (2005) Effects on smear layer and debris removal with varying volumes of $17 \%$ REDTA after rotary instrumentation. J Endod 31: 536-538.

30) Teixeira CS, Felippe MC, Felippe WT (2005) The effect of application time of EDTA and $\mathrm{NaOCl}$ on intracanal smear layer removal: an SEM analysis. Int Endodontic J 38: 285-290.

31) Sabins RA, Johnson JD, Hellstein JW (2003) A comparison of the cleaning efficacy of short term sonic and ultrasonic passive irrigation after hand instrumentation in molar root canals. J Endod 29: 674-678. 32) Chopra S, Murray PE, Namerow KN (2008) A scanning electron microscopic evaluation of the effectiveness of the F-file versus ultrasonic activation of a K-file to remove smear layer. J Endod 34: 1243-1245.

33) Jiang LM, Verhaagen B, Versluis M, Langedijk J, Wesselink P (2011) The influence of the ultrasonic intensity on the cleaning efficacy of passive ultrasonic irrigation. J Endod 37: 688-692.

34) Alacam T (1987) Scanning electron microscope study comparing the efficacy of endodontic irrigating systems. Int. Endodontic J 20: 287-294.

35) Cameron JA (1983) The use of ultrasonics in the removal of the smear layer: a scanning electron microscope study. J Endod 9: 289292.

36) Cheung GSP, Stock CJR (1993) In vitro cleaning ability of root canal irrigant with and without endosonics. Int Endodontic J 26: 334-343.
37) Baumgartner JC, Cuenin PR (1992) Efficacy of several concentrations of sodium hypochlorite for root canal irrigation J Endod 12: 605-612.

38) Guerisoli DM, Marchesan MA, Walmsley AD, Lumley PJ, Pecora JD (2002) Evaluation of smear layer removal by EDTAC and sodium hypochlorite with ultrasonic agitation. Int. Endodontic J 35 418-421.. 39) Cameron JA (1995) Factors affecting the clinical efficiency of ultrasonic endodontics: a scanning electron microscopy study. Int Endodontic J 28: 47-53.

40) Abbott PV, Heijkoop PS, Cardaci SC, Hume WR, Heithersay GS (1991) An SEM study of the effects of different irrigation sequences and ultrasonics. Int. Endodontic J 24: 308-316.

41) Pérez-Heredia M, Ferrer-Luque CM, Gonzalez-Rodriguez MP (2006) The effectiveness of different acid irrigating solutions in root canal cleaning after hand and rotary instrumentation. J Endod 32: 993-997.

42) Ferrer Luque CM, Gonza'lez Lo'pez S, Navajas Rodri'guez, de Mondelo JM (1996) Mechanical instrumentation of the root canals: a study using SEM and computerized image analysis. Bull. Group Int. Rech. Sci. Stomatol. Odontol. 39: 111-117.

43) Khedmat S, Shokouhinejad N (2008) Comparison of the efficacy of three chelating agents in smear layer removal. J Endod 34: 599-602.

44) Mancini M, Armellin E, Casaglia A, Cerroni L, Cianconi L (2009) A comparative study of smear layer removal and erosion in apical intraradicular dentine with three irrigating solutions: a scanning electron microscopy evaluation. J Endod 35: 900-903.

\section{Submit your manuscript to a JScholar journal} and benefit from:

ฯ Convenient online submission

ฯ Rigorous peer review

I Immediate publication on acceptance

ब Open access: articles freely available online

9. High visibility within the field

I Better discount for your subsequent articles

Submit your manuscript at http://www.jscholaronline.org/submit-manuscript.php 